\title{
EN LOS ORÍGENES DE LA RETABLÍSTICA NEOGRANADINA: TRAZAS Y CONTRATO PARA UN RETABLO DE TUNJA (1586)
}

\author{
IN THE ORIGINS OF NEW GRANADA'S ALTARPIECES: \\ DESIGNS AND CONTRACT FOR AN ALTARPIECE IN \\ TUNJA (1586)
}

\author{
Francisco Javier Herrera García \\ Universidad de Sevilla. España \\ fjherrera@us.es \\ Laura Liliana Vargas Murcia \\ Universidad Nacional de Colombia. Colombia \\ lauralilivm@gmail.com
}

Los orígenes del retablo en la Nueva Granada (actual República de Colombia) siguen en gran medida desconocidos. Las necesidades de la evangelización y la voluntad patrocinadora de los habitantes españoles irían impulsando el arte de la escultura y la arquitectura de retablos en la segunda mitad del siglo XVI. Tunja es uno de los núcleos fundamentales de la antigua Audiencia de Santafé (Bogotá) desde el punto de vista artístico. Damos a conocer el contrato para un retablo destinado al humilladero de La Soledad, de 1586, obra del carpintero Andrés de Granado.

Palabras clave: retablo; Nueva Granada; Tunja; Andrés Granado; Bartolomé Moya.

The origins of the altarpiece art in New Granada (present Republic of Colombia) remain largely unknown. The needs of evangelization and the sponsor of the Spanish citizens would push the art of sculpture and architecture of altarpieces in the second half of the $16^{\text {th }}$ century. Tunja is one of the fundamental centers of ancient Audiencia of Santafé (Bogotá) from an artistic point of view. We report the contract for an altarpiece destined to La Soledad calvary in 1586. It was made by the carpenter Andrés Granado.

Keywords: altarpiece; New Granada; Tunja; Andrés Granado; Bartolomé Moya.

Tanto en la Nueva Granada (Colombia) como en otras regiones americanas, resulta difícil precisar el desarrollo inicial y arranque de la arquitectura de retablos, pensada al igual que en Europa, para enmarcar, distinguir y organizar 
imágenes pictóricas o escultóricas. De forma parecida a lo acaecido en la península Ibérica desde tiempos bajomedievales, en América el retablo será una solución artística llamada a gozar de especial éxito, materializado desde los días cercanos a la conquista cuando fue utilizado como instrumento al servicio de la evangelización de las sociedades indígenas, y a lo largo de los siguientes siglos, de manera que se erige en peculiar medio expresivo y ornamental de los templos, a la vez que cumple una serie de funciones de índole dogmático, doctrinal, litúrgico, etc., ya conocidas.

La necesidad de imágenes pictóricas y escultóricas para atender las exigencias catequéticas y de ornato de los primeros templos, cuando no existían artífices formados en la elaboración de piezas artísticas mejor elaboradas, llevó al empleo de materias primas elementales para contener esas sencillas pinturas o guarnecer esculturas, y se haría uso de las habilidades indígenas que podrían resultar más apropiadas para estos fines. Se da por supuesto la fácil reconversión de la mano de obra indígena especializada en labores textiles, alfarería, orfebrería, talla de la madera y pintura, a las nuevas prácticas artísticas importadas de España. Sin embargo, la documentación y los testimonios materiales de tales creaciones escasean o han desaparecido. Ya hemos dado cuenta del empleo de las tradicionales mantas de algodón, una de las producciones distintivas y peculiares de los pueblos prehispánicos de la meseta cundiboyacense, para ornamentar presbiterios, conteniendo episodios evangélicos o santos pintados, así como resguardando los altares a modo de ciborio o dosel - "cielos" - ${ }^{1}$ (Figura 1). También de cordobanes pintados y elementales marcos $u$ hornacinas abiertas en la pared que podrían funcionar a modo de sencillas formas retablísticas. No olvidemos, en este rápido repaso, las imágenes pintadas sobre los muros, aún subsistentes en numerosas

${ }^{1}$ Sin duda, máximo ejemplo del empleo de las mantas o lienzos de la tierra, confeccionados por mano de obra indígena con algodón, para disponer una imagen de culto, es el de la Virgen del Rosario de Chiquinquirá, patrona actual de Colombia, pintada sobre una de esas mantas por el pintor natural de Alcalá de Guadaíra (Sevilla) Alonso de Narváez hacia 1555, establecido en Tunja. ROMERO SÁNCHEZ, Guadalupe: "Alonso de Narváez, pintor andaluz establecido en Tunja”, en LÓPEZ GUZMÁN, Rafael (coord.): Andalucía y América. Patrimonio artístico. Granada, 2011, pp. 13-30. La bibliografía sobre la Virgen del Rosario de Chiquinquirá es muy extensa; destacamos los recientes trabajos de ACOSTA LUNA, Olga Isabel: Milagrosas imágenes marianas en el Nuevo Reino de Granada. Madrid-Frankfurt, 2011, pp. 79-81 y 214-226; ACOSTA LUNA, Olga Isabel: "Una manta más ancha que larga. Nuestra Señora de Chiquinquirá y la institucionalización de una imagen milagrosa en el Nuevo Reino de Granada"; y CUMMINS, Tom: "On the Colonial Formation of Comparison: The Virgin of Chiquinquirá, The Virgin of Guadalupe and cloth", Anales del Instituto de Investigaciones Estéticas, 74-75, 1999, pp. 67-74. Sobre las mantas de tradición muisca y su empleo como soporte pictórico véase VARGAS MURCIA, Laura Liliana: "De Nencatacoa a San Lucas: Mantas muiscas como soporte pictórico en el Nuevo Reino de Granada", Ucoarte, 4, 2015, pp. 25-43. 
iglesias colombianas, mediante las técnicas del temple y a la cal, muchas de las cuales funcionarían como auténticos retablos pintados ${ }^{2}$.

El imaginario que lentamente se introduce en las iglesias doctrineras de los pueblos de indios, se adivina pobre y limitado. Ni que decir tiene, las iglesias urbanas, catedrales, de órdenes religiosas como dominicos, agustinos, jesuitas y franciscanos, llevarían la delantera en la provisión de ornamentos de mejor calidad artística, especialmente retablos, y eso fue posible gracias al poder económico de las respectivas comunidades, al patrocinio particular que importa imágenes escultóricas y retablos y al patronato real que se puso de relieve de forma singular en las catedrales.

Tal como observa Guadalupe Romero, el ornato de las iglesias doctrineras es precario, destacando en la segunda mitad del XVI y hasta avanzado el XVII, la escasez de utensilios litúrgicos, ornamentos textiles, misales y, sobre todo, imágenes adecuadas. Apenas existen noticias sobre máquinas retablísticas de cierta envergadura hasta entrado el XVII y, en su lugar, las citadas mantas y guadamecíes pintados, algunas pinturas de caballete o imágenes aisladas, suplían las necesidades iconográficas más elementales ${ }^{3}$. Si bien las comunidades dispuestas bajo la autoridad real, a través de la Audiencia santafereña, estaban mejor paradas en este asunto, al menos en lo más básico, como era la construcción de los edificios y la provisión de útiles litúrgicos, ornamentos textiles, cálices y campanas, no ocurría lo mismo con los pueblos de indios usufructuados y regidos por encomenderos, sobre los que se intensificó la vigilancia, por parte de las autoridades eclesiásticas, en las décadas finales del XVI y primeras del XVII, ante la recurrente dejadez y desinterés de los poseedores de estas encomiendas por el ornato de los templos y la evangelización de indios, intensamente explotados por el régimen encomendero. Todos los datos que conocemos abundan en esa dirección: el escaso interés en la evangelización, cosa que crispa a las autoridades episcopales con frecuencia, la negativa a invertir en las fábricas y ornamentos y, en mayor

${ }^{2}$ HERRERA GARCÍA, Francisco Javier y GILA MEDINA, Lázaro: "El retablo escultórico del siglo XVII en la Nueva Granada (Colombia). Aproximación a las obras, modelos y artífices", en GILA MEDINA, Lázaro (coord.): La consolidación del Barroco en la escultura andaluza e hispanoamericana. Granada, 2013, pp. 301-368, de la cita pp. 307-309.

3 ROMERO SÁNCHEZ, Guadalupe: Los pueblos de indios en Nueva Granada: trazas urbanas e iglesias doctrineras. Granada, 2008 (tesis doctoral), pp. 247, 251, 252, 571, 1.216, 1.917, 3.333 y 3.359; ROMERO SÁNCHEZ, Guadalupe: Los pueblos de indios en Nueva Granada. Granada, 2010; ROMERO SÁNCHEZ, Guadalupe: Iglesias doctrineras y trazas urbanas en Nueva Granada. Granada, 2012; ROMERO SÁNCHEZ, Guadalupe: "Las iglesias de realengo de Cundinamarca y Boyacá: construcción y provisión de ornamentos", en LÓPEZ CALDERÓN, Carme; FERNÁNDEZ VALLE, María de los Ángeles y RODRÍGUEZ MOYA, María Inmaculada (coords.): Barroco Iberoamericano: identidades culturales de un Imperio. Santiago de Compostela, 2013, pp. 173-188. 
medida, la oposición a proporcionar indígenas hábiles en construcción y otras labores convenientes a las sencillas iglesias doctrineras ${ }^{4}$.

El control del ornato y decencia de los templos adquiere relieve en la prelatura de dos Arzobispos de Santafé, como fueron Luis de Zapata de Cárdenas (1570-1590) y Bartolomé Lobo Guerrero (1596-1607). El primero redactó en 1576 un catecismo orientado a los indios y muestra especial preocupación por el ajuar litúrgico y ornato de los templos ${ }^{5}$, mientras el segundo, dotado de fuerte determinación en las tareas de fortalecimiento del cristianismo y la iglesia diocesana en el Nuevo Reino, estableció la orden jesuítica, fundó el seminario diocesano, el colegio de San Bartolomé y no olvidemos la expedición de las constituciones sinodales, en 1606, así como la concienzuda vigilancia sobre las iglesias doctrineras, en particular las regidas por encomenderos. Ordenó rigurosas visitas y penalizó el desinterés con los templos por parte de encomenderos, para lo cual contó con el apoyo de los presidentes de la Real Audiencia, como Francisco de Sande y Juan de Borja ${ }^{6}$, institución con cuyos oidores discrepó en ocasiones por cuestiones relativas a las competencias de su ministerio y del poder judicial ${ }^{7}$. Precisamente, en las citadas constituciones de 1606 se establecen todos los ornamentos precisos en cada iglesia, inventariando un conjunto de enseres muy superior al de años atrás, sin faltar la mención a "un retablo o imagen y un tabernáculo de madera". No hace falta explicar que estas alusiones no se corresponden con una estructura retablística de cierto porte, sino con elementales recuadros para contener imágenes pictóricas o escultóricas y el sagrario-expositor. Con este indudable impulso al equipamiento de las doctrinas, sobre todo se atendió al ajuar metálico y textil

${ }^{4}$ ROMERO SÁNCHEZ, Guadalupe: "Las iglesias de realengo...”, op. cit., pp. 173188; y CHICA SEGOVIA, Angélica: "El simbolismo del templo cristiano presente en las iglesias de pueblos de indios del Altiplano Cundiboyacense construidas entre 1579 y 1616 : la sencillez de lo mínimo necesario", en Visiones renovadas del Barroco iberoamericano. Vol. 1. Sevilla, 2016, pp. 8-43.

5 "Capítulo 43. Del ornato del altar. Item. Procurará el sacerdote como el altar esté adornado con imágenes, frontal, y manteles; todo muy limpio; y, ainsí mismo, en todo lo tocante a este santo misterio, como cáliz, ara, corporales, purificadores, paños de cáliz y de manos, y palias... Y también tendrá la misma curiosidad y limpieza en las vestimentas sacerdotales, teniéndolas muy labradas y muy bien dobladas con mucha curiosidad, y guardadas en su caja diputada para esto. Y no consienta que las traten indios, antes les de a entender que todo aquello es tan santo, que no pueden tocar..." MARÍN TAMAYO, John Jairo: La construcción de una nueva identidad en los indígenas del Nuevo Reino de Granada. La producción del catecismo de fray Luis Zapata de Cárdenas (1576). Bogotá, 2008, p. 300.

${ }^{6}$ SANTOFIMIO ORTIZ, Rodrigo: "Don Bartolomé Lobo Guerrero, tercer Arzobispo del Nuevo Reino de Granada (1599-1609), y el proceso de cristianización en la alta colonia", Anuario colombiano de historia social y de la cultura, vol. 38, 1, 2011, pp. 17-49.

${ }^{7}$ Ibidem, pp. 25-29.

${ }^{8}$ Apéndice documental $n^{\circ} 1$. 
necesario para las celebraciones eucarísticas, administración de sacramentos, sin que cobre importancia o se considere obligatorio el ornamento interno, especialmente retablos, salvo los sencillos marcos para imágenes que ya hemos referido.

Las visitas ordenadas por el arzobispo Lobo a las doctrinas de encomenderos, arrojan un panorama desolador. Según expone el listado de penas monetarias impuestas por carecer de ajuar y ornato esencial, de 27 de noviembre de 1599, en la mayoría de los templos faltaban retablos, al menos una elemental estructura de madera para servir de guarnición a una imagen, preferentemente pictórica, lo cual invita a pensar que también carecían de esculturas o pinturas. Este revelador documento ${ }^{9}$, no solo es útil para comprobar la desatención recurrente de los encomenderos respecto a sus templos, la mayoría construcciones de bahareque cubiertas de paja, así como la escasez de casi todo lo imprescindible para el culto, campanas o vasos sagrados ${ }^{10}$. Interesa igualmente comprobar el destino del importe de las multas, dos terceras partes para cubrir gastos de la visita y un tercio en casi todos los casos de multados, se aplicaría a la obra del retablo de Vélez, una villa de realengo donde parece que aquel año se avanzaba en la disposición de un retablo de cierta envergadura ${ }^{11}$, quizás el mismo para el que en 1606 se proveyera un lienzo de gran tamaño con las imágenes de la Trinidad, la Virgen y los doce Apóstoles, obra del pintor Simón de Lora ${ }^{12}$.

Frente a la precariedad de las iglesias doctrineras, los conventos, parroquias de Tunja y Santafé, así como la catedral ubicada en esta última ciudad, fueron las que disfrutaron de algunos retablos y mobiliario para el culto, como púlpitos o $\operatorname{coros}^{13}$. El favor real y, sobre todo, el patrocinio privado, jugaron un papel fundamental. Aunque hemos de tomarlos con cautela, ciertos testimonios dejan

9 Apéndice documental $\mathrm{n}^{\circ} 2$.

${ }^{10}$ Esta desatención de los encomenderos a sus templos venía de antes, así lo hizo constar don Diego de Torres, célebre cacique de Turmequé, en 1578, al rey Felipe II, en el memorial que le dirigió en nombre de "todos los naturales del dicho Nuevo Reino: Iglesias y ornamentos. $6^{\circ}$. Está mandado por cédula real de S. M. que los encomenderos tengan iglesias en los pueblos y repartimientos que les fueren encomendados, que tengan ornamentos y todo lo necesario para el culto divino. No se ha cumplido ni cumple porque las iglesias que están en los dichos repartimientos sirven de cárceles privadas a donde prisionan los pobres indios como es notorio a los que han estado en aquellas partes". ROJAS, Ulises: El cacique de Turmequé y su época. Tunja, 1965, p. 55.

${ }^{11}$ Apéndice documental $\mathrm{n}^{\circ} 2$.

12 VARGAS MURCIA, Laura Liliana: Del pincel al papel: Fuentes para el estudio de la pintura en el Nuevo Reino de Granada (1552-1813). Bogotá, 2012, pp. 134-135.

13 A pesar de todo, en los años centrales del XVI es raro el templo que no lamente su precariedad en útiles litúrgicos, como la iglesia mayor de Tunja, cuando todavía era una especie de bohío, que había sufrido un incendio en 1552 y después de reconstruida, hacia 1557 carecía de todo tipo de ornato y útiles litúrgicos. PORRAS COLLANTES, Ernesto: "Historia del primer templo mayor de Tunja, nombrado de Nuestra Señora de 
entrever lo aventajadas en ornato interno que se encontraban algunas comunidades. Fray Pedro de Aguado declaraba en 1575, cómo bajo sus órdenes en el convento seráfico de Santafé, se habían reparado y construido celdas "y otras cosas que hize rreparar y el coro y asientos de madera labrada que está hecho en el dicho monasterio y adornado la iglesia y altares de ella de muchos ornamento"14. Años después, en 1582, doña María de Oriego, viuda del capitán y conquistador Antonio de Olalla, se obligaba a fundar capellanía en la capilla del Crucifijo, en la nueva catedral que entonces se levantaba en Santafé, dotándola de numerosos ornamentos, entre otros "el rretablo e ymagenes que convengan para el servicio de la dha. Capellanía que en ella e de fundar, pondré a mi costa los ornamentos e frontales, caliz e ara, misales, e lo demás que sea nesçesario para el servicio del culto divino"15. Constituye un buen exponente de la contribución de particulares a la dotación de retablos en los templos, como también vemos en Tunja por esos años, en primer lugar en el conocido caso de la capilla de la Vera Cruz o del capitán Antonio Ruiz Mancipe de su iglesia mayor, provista del retablo aún subsistente confeccionado, junto a sus imágenes escultóricas, por Juan Bautista Vázquez el Viejo en Sevilla en 1583. Singular es el ejemplo de Juan de Porras Marquina y María de Onora, que en 1592 encargaron en Sevilla un conjunto escultórico compuesto por San Juan Bautista, San Diego, una Virgen y dos ángeles, al parecer integrando un retablo destinado a la iglesia tunjana de San Francisco, que no debe coincidir con el que actualmente vemos, donde se ubican las dos primeras imágenes ${ }^{16}$. La citada Virgen puede tratarse de la actual Inmaculada, resguardada en un camarín de la nave de la epístola de este templo, imagen mutilada y revestida en tiempos barrocos, cuyo examen detenido delata una factura sevillana de la última década del siglo XVI, vinculable a los herederos de Jerónimo Hernández.

Guadalupe", Anuario colombiano de historia social y de la cultura, 31, 2004, pp. 33-44, de la cita p. 40, n. 38 .

${ }^{14}$ LÓPEZ RODRÍGUEZ, Mercedes: Tiempos para rezar y tiempos para trabajar. Bogotá, 2001, p. 61.

${ }^{15}$ En la solicitud para construir la nueva capilla, "çercar y çerrar con su rexa y puerta y aderesçarla de rrecaudos y ornamentos nesçesarios y tener en ella my entierro y asiento para mi y para mis hijos y erederos sinque en la dha. capilla se le diese asiento y sepoltura a otras personas alguna..., se compromete además a donar a la catedral por la cesión de la capilla quatroçientos pesos de oro de a veynte qes. y dos capas de damasco carmesy con sus çenefas y capillas de terciopelo carmesy y bordadas con algún rromano de rraso cortado y dorçales de seda". Archivo General de Indias (A.G.I.), Gobierno, Audiencia de Santafé, 231.

${ }^{16}$ GILA MEDINA, Lázaro y HERRERA GARCÍA, Francisco Javier: "Escultores y esculturas en el Reino de la Nueva Granada (Colombia)", en GILA MEDINA, Lázaro (coord.): La escultura del primer naturalismo en Andalucía e Hispanoamérica. 1580-1625. Madrid, 2010, pp. 502-562, de la cita pp. 512-513. 
La ciudad de Tunja, que había sido fundada el 6 de agosto de 1539 por Gonzalo Suárez Rendón, experimenta un notable crecimiento a lo largo de la segunda mitad del XVI. Allí se establecieron muchos conquistadores y su descendencia, encomenderos beneficiados del reparto de indios en los extensos territorios de su entorno, inmigrantes peninsulares de cierto abolengo, que ahora construyen casas y pregonan su origen hidalgo. Su rica economía agrícola y ganadera, sin olvidar la actividad comercial implantada por los españoles, hacen de esta ciudad un núcleo de primera línea en el Nuevo Reino, compitiendo en pujanza con la sede de la Audiencia y Arzobispado de Santafé ${ }^{17}$. Ya señalamos la dedicación de esta nueva sociedad mestiza y criolla a la promoción de empresas artísticas, no solo ayudan a la construcción de la iglesia mayor, sino también a las fábricas de franciscanos, dominicos, agustinos y jesuitas, sin olvidar los conventos de monjas como los de Santa Clara y la Concepción, por citar los templos más destacados. La arquitectura, el arte de la cantería aplicada a la anterior, la pintura mural y de caballete, así como la arquitectura de retablos y la escultura, adquieren rápido desarrollo, auspiciado por los artistas llegados de la Península y por las continuas importaciones de obras que sirven de modelo. Las ideas y cultura del humanismo fueron difundidas por una serie de intelectuales como el vicario Juan de Castellanos, el escribano Juan de Vargas, el clérigo Juan de Leguizamón o el capitán Antonio Ruiz Mancipe ${ }^{18}$.

Nos interesan ahora las dos últimas décadas del siglo, los años ochenta y noventa del XVI, momento de efervescencia constructiva y ornato de los nuevos templos. La iglesia mayor iniciada en 1567, después de incendiarse el primitivo bohío, se finaliza en 1600 . Entre 1598 y el citado año de 1600 se le dotó de su portada, obra cumbre del Renacimiento neogranadino, acometida por el maestro Bartolomé Carrión, fiel reflejo del humanismo entonces triunfante entre la élite culta de la ciudad ${ }^{19}$. Parecida cronología constructiva podemos barajar para iglesias como la de Santo Domingo (c. 1559-c. 1600). Entre 1571 y 1574 tuvieron lugar las obras del convento de Santa Clara, si bien la decoración de su iglesia no se completa hasta la centuria siguiente. Los agustinos finalizan su templo en 1603 y los franciscanos ven transcurrir las obras de su complejo conventual con lentitud,

${ }^{17}$ MORAles FOLGUERA, José Miguel: Tunja. Atenas del Renacimiento en el Nuevo Reino de Granada. Málaga, 1998, pp. 39-82.

${ }_{18}$ Ibidem, pp. 21-25.

${ }^{19}$ MARCO DORTA, Enrique: "La arquitectura del Renacimiento en Tunja”, Revista de Indias, 9, 1942, pp. 463-513, de la cita pp. 464-475; ROJAS, Ulises: El beneficiado don Juan de Castellanos cronista de Colombia y Venezuela. Tunja, 1958, pp. 95-127; ARBELÁEZ CAMACHO, Carlos: "La Catedral de Tunja", Anales del Instituto Americano de Arte e Investigaciones Estéticas, 18, 1965, pp. 7-26, de la cita pp. 7-15; CORRADINE ANGULO, Alberto: La arquitectura en Tunja. Bogotá, 1990, pp. 51-57; y MORALES FOLGUERA, J. M.: Tunja. Atenas del Renacimiento..., op. cit. pp. 83-120. 
intensificándose en la última década del siglo y finalizándose algo después de 1610. Con posteridad a 1611 se inicia la construcción de la iglesia de los jesuitas. No olvidemos las ermitas de San Laureano, consagrada en 1574 y ornamentada en los años siguientes, así como la de San Lázaro, erigida en torno a $1587^{20}$. Con este rápido repaso de las principales cronologías constructivas de las iglesias tunjanas, queremos destacar el impulso artístico que debió acarrear esa actividad. No debe extrañarnos las importaciones de obras desde Sevilla, como el establecimiento de artífices capaces de dotar de imágenes, retablos, talla ornamental, etc., a los templos que al finalizar el siglo se concluyen.

Las noticias que tenemos para Tunja sobre establecimiento de escultores y tallistas o ensambladores de retablos en estas décadas postreras del XVI, son muy escasas. Apenas han trascendido algunos nombres como los maestros Francisco Velázquez y Amador Pérez, maestros carpinteros vecinos de Villa de Leyva, que se desplazan a la ciudad para acometer la obra de la sillería catedralicia, en torno a 1598. En las décadas anteriores, sin duda, debió existir un panorama muy parecido al que conocemos para Santafé y otros puntos del Nuevo Reino, cuando en 1565 el mercader Cristóbal Rodríguez Cano solicitaba un oficial para hacer retablos que trabajara en la capital, pues no existían peritos en estas artes en toda la región. Años más tarde, en 1572, recordamos el paso del sevillano Alonso Rodríguez, carpintero entallador, a la misma ciudad para ocuparse en diversas obras de carpintería de la catedral y conventos ${ }^{21}$. Este tipo de profesionales versátiles han dejado atrás el estricto control gremial y las ordenanzas peninsulares, que restringían y acotaban el ejercicio de sus especialidades. Este perfil profesional más abierto y menos restrictivo, debió ser frecuente en estos momentos, de manera que no sería extraña su habilidad en el ensamblaje y talla, con rudimentarios conocimientos de gramática arquitectónica, en la carpintería de armar, confección de artesonados, mobiliario civil y litúrgico e incluso retablos. Quizás en esta línea podríamos contemplar a uno de los carpinteros activos en Tunja en la segunda mitad del siglo, nos referimos a Bartolomé Moya, oriundo de la ciudad andaluza de Córdoba, donde se instruyó en el arte de la carpintería de lo blanco y quizás en otras facetas carpinteriles, que luego emplea en Tunja ${ }^{22}$. De momento se le ha

${ }^{20}$ MARCO DORTA, E.: “La arquitectura del Renacimiento...”, op. cit., pp. 475-492; CORRADINE ANGULO, A.: La arquitectura en Tunja..., op. cit., pp. 57-86; y MORALES FOLGUERA, J. M.: Tunja. Atenas del Renacimiento..., op. cit. pp. 39-63.

${ }^{21}$ GILA MEDINA, L. y HERRERA GARCÍA, F.: "Escultores y esculturas...”, op. cit., pp. 510-511; y ROMERO SÁNCHEZ, Guadalupe: "Licencia de pasajero: destino Santafé. Las pesquisas sobre Alonso Rodríguez, carpintero sevillano en el siglo XVI”, en LÓPEZ GUZMÁN, R.; GUASCH MARÍ, Y. y ROMERO SÁNCHEZ, G.: América: cultura visual y relaciones artísticas. Granada, 2015, pp. 95-103.

${ }_{22}$ Desde 1567 pretendió acceder a las obras de carpintería de la parroquia tunjana, de manera que presenta un memorial en el que declara que "había hecho obras mucho más 
relacionado con la construcción del artesonado de la iglesia mayor, actual catedral tunjana, entre 1572 y $1574^{23}$ (Figura 2). Fue artífice de confianza del erudito vicario Juan de Castellanos, a quien debió en gran medida su vinculación a esta fábrica ${ }^{24}$. Parece que con su oficio amasó fortuna en Boyacá, convertido en una figura destacada de la carpintería tunjana y ocupándose de las obras de varias iglesias. Llegó a ser maestro mayor de obras de carpintería de la parroquia mayor ${ }^{25}$. Caso parecido pudo ser el del también carpintero Juan Estévez a quien contrató el alcalde ordinario de la ciudad en 1592, para aserrar toda la madera precisa en las obras de las iglesias mayor, San Francisco, Santo Domingo y Santa Clara ${ }^{26}$.

importantes y delicadas en la ciudad de Córdoba en España y era viejo en el oficio", al tiempo que declara estar examinado en carpintería. ROJAS, U.: El beneficiado..., op. cit, pp. 104-105.

${ }^{23}$ Ibidem, pp. 104-116; y CORRADINE ANGULO, A.: La arquitectura en Tunja..., op. cit., pp. 53-54.

${ }^{24}$ Sobre su intervención en la iglesia mayor y conflictos con otros dos carpinteros, García González Jaramillo y Alonso de Mora, por la adjudicación de las obras del artesonado, véase PORRAS COLLANTES, Ernesto: Crónica colonial de Tunja y su provincia. Tunja, 2006, pp. 88-115.

${ }^{25}$ Bartolomé de Moya solicitó por carta, el 20 de marzo de 1580, a su hija Catalina de Moya, residente en Córdoba, su traslado a la Nueva Granada en compañía de su esposo Juan Sánchez, también del mismo oficio, animándola de las buenas perspectivas laborales que ofrece el país, pues el llegó en circunstancias precarias y ahora es rico, dispone de esclavos oficiales y sobre los comitentes tunjanos, dice "están muy aficionados a mi... y la puedo yo hacer mejor [iglesia mayor de Tunja] que cuantos hay en toda la tierra". OTTE, Enrique: Cartas privadas de emigrantes a Indias, 1540-1616. Sevilla, 1988, p. 324. En virtud de real cédula otorgada por Felipe II en 1582, Juan Sánchez y Catalina de Moya emprendieron el viaje para reunirse con su suegro y padre en Tunja, "el qual diberças beces nos a mandado llamar para nos favoresçer y ayudar por estar muy rico y acendado". Uno de los testigos en esta información que citamos, Agustín Verdugo, estante en Madrid pero vecino de Tunja, declara que conoce a Bartolomé de Moya, que vive "en la dha. Ciudad de Tunja y enella tiene casa y familia y esclavos y hace la obra de la iglesia mayor de la dha. Ciudad y le va bien", agregando que el citado Juan Sánchez y Catalina de Moya "les estaba bien pasar a aquellas ptes. con el dho. Bme. de Moya especialmte. siendo como dicen que es el dho. Juan Sanchez offal. de carpintero el dho. su suegro le favorecía especialmente aviendo como ay necesidad de oficiales en aquella tierra para acavar la yglesia mayor y otras obras que ay, e a ella pasarían mexor e mas acomodadamente". Otro de los testigos, Álvaro Suárez de Deza, declara conocer a Bartolomé de Moya y saber que vive en Tunja desde hace más de quince años, agregando la conveniencia de que Juan Sánchez y su mujer pasen a esa ciudad "porque a su offo. ganaría bien de comer en aquella tierr ${ }^{\mathrm{a}}$ por haber buenas obras e muchas e pocos offiçiales e porque dho. Bme. de Moya le acomodaría muy bien porque tiene a su cargo la obra de la Yglesia mayor de la dha. ciudad de Tunja y otras obras y es hombre viejo y tiene rrazonablemente lo que es menester tener". A.G.I., Indiferente, 2093, N. 38.

${ }^{26}$ CORRADINE ANGUlO, A.: La arquitectura en Tunja..., op. cit., p. 54. 
Numerosos carpinteros figuran vinculados a los trabajos lignarios de la iglesia mayor, Francisco Abril, declarado enemigo de Moya, Juan Bautista, maestre Juan, Francisco de Chinchilla, Francisco de León, Francisco Martín, Juan Ramón, Andrés de la Cueva, Diego Serrano, Bartolomé de Segovia y Joan o Juan de Vergara, este último citado en ocasiones como entallador, y otras "imaginario" 27.

No debemos dejar de lado la idea de trabajo multidisciplinar entre los oficiales de la madera, desprendidos ya de las estrictas limitaciones de las ordenanzas peninsulares y ávidos de asumir encargos que les proporcionaran sustanciosas ganancias. Es posible que dentro de este perfil encajara la figura del carpintero Andrés Granado, sobre la que ahora nos extenderemos. El 29 de mayo de 1586 concertaba con la hermandad de la Soledad tunjana, establecida en el humilladero situado en la salida occidental de la ciudad, la confección de un retablo para disponer en él las imágenes que tenía la cofradía. Debería estar finalizado en el plazo de seis meses. Importaba su trabajo 130 pesos de oro fundido con la marca de su majestad y 20 quilates de ley, 50 de los cuales percibe al firmar el contrato y los 80 restantes al quedar asentado. Los mayordomos de la cofradía, Pedro Pacheco Carvajal, Alonso de Carvajal y Esteban Gómez, se comprometen a entregar toda la madera precisa ${ }^{28}$. El primero de los mencionados, Pedro Pacheco, fue fundador y principal protector de la citada hermandad de la Soledad. En un juicio que se le siguió en 1596 por varias causas, uno de los testigos, el clérigo Cristóbal de Sanabria, declaraba sobre su persona ser "hombre honrado y principal [...] buen cristiano y por muy leal vasallo de su Majestad [...] este testigo ha visto al dicho Pedro Pacheco ocupado muchas veces en servicio de las cofradías que están fundadas en esta ciudad y principalmente en la de Nuestra Señora de la Soledad dando limosna

${ }^{27}$ PORRAS COLLANTES, E.: Crónica colonial de Tunja..., op. cit. pp. 68, 116, 117 y 123.

${ }^{28}$ Véase apéndice documental $n^{\circ} 3$. Los mayordomos de la cofradía son el capitán Pedro Pacheco Carvajal, Alonso de Carvajal y Esteban Gómez. Entre los testigos firma Juan Sánchez, quizás el carpintero yerno de Bartolomé de Moya, que se desplazó a Tunja en 1582, en compañía de su esposa. Véanse notas al pie n 24 y 25. Los Carvajales eran una familia de abolengo en la ciudad. Alonso de Carvajal fue encomendero, capitán y en 1594 se opuso a las nuevas alcabalas. A su cargo tenía cuatro pueblos de indios. El primero de los nombrados en el documento, Pedro Pacheco Carvajal, fue su hermano, ambos hijos de Diego García de Pacheco, de los primeros conquistadores de Santa Marta y Francisca de Carvajal. Pedro sería regidor de Tunja y también notable encomendero. FLÓREZ DE OCÁRIZ, Iván: Libro segundo de las genealogías del Nuevo Reyno de Granada. Madrid, 1676, p. 199; FERNÁNDEZ PIEDRAHITA, Lucas: Historia general de las conquistas del Nuevo Reyno de Granada a la S.C.R.M. de Don Carlos Segundo, Rey de las Españas, y de las Indias. Amberes, 1688, p. 229; y CORTÉS ALONSO, Vicenta: “Tunja y sus vecinos", Revista de Indias, 99-100, 1965, pp. 155-207, de la cita p. 164. Véase el capítulo "El motín de las alcabalas" en LIÉVANO AGUIRRE, Indalecio: Los grandes conflictos sociales y económicos de nuestra historia. T. I. Bogotá, 1968, pp. 149-166. 
de su hacienda y pidiéndola a otros para el culto y aumento de la cofradía" 29 . En el mismo pleito, para su defensa, fue previsto un interrogatorio en el que se alude a la fundación de la citada hermandad de la Soledad y su fidelidad a las disposiciones de la autoridad eclesiástica respecto a las salidas procesionales ${ }^{30}$.

El contrato para el retablo de la Soledad es de gran importancia pues permite establecer la actividad en el campo del retablo de un taller de carpintería tunjano de finales del XVI y la génesis de un modelo que tendrá enorme difusión en la siguiente centuria, aparte de brindarnos el nombre de un artista del que, de momento, no tenemos otras noticias. Pero, quizás, mucho más que el instrumento contractual en si, de mayor relevancia es que le acompañe la traza confeccionada por Granado y firmada por el escribano Juan de Vargas ${ }^{31}$.

El diseño (Figura 3) nos enseña las limitadas habilidades en el arte del dibujo del carpintero, ofreciendo una muestra pobre, esquemática, muy lineal, carente de detalles ornamentales y sin referencias proporcionales. Carece de escala lo que da pie a pensar que las citadas proporciones, según vemos en la hoja del legajo, no se corresponden para nada con las reales, al deberse adaptar a las medidas de la cabecera del desaparecido templo. Tampoco el contrato señala dimensiones, de manera que sería el testero el que marca la pauta de sus mensuras. Consta de dos cuerpos elevados sobre banco, con entablamentos rectos delimitándolos. Verticalmente se divide en tres calles de igual anchura y por remate, frontón triangular abarcando todo el conjunto. Resulta, por tanto, una sencilla estructura de casillero, con hornacinas en el primero y en la calle central del segundo, cada una de ellas articuladas por columnas de fuste estriado con capiteles de impresión corintia o compuesta. Esta organización nos habla de un autor que quizás tome ideas de la retablística castellana o andaluza de tendencia romanista, de mediados o segunda mitad del XVI. Como únicos detalles ornamentales insinuados en el dibujo podemos referirnos a las superficies apiramidadas de las enjutas, en las hornacinas del primer cuerpo, una especie de triglifos en el friso del entablamento intermedio, así como el medio punto avenerado de la hornacina central del cuerpo superior, elemento este que fue habitual en la Península en el retablo de tendencia plateresca y ahora vemos como se afinca en la Nueva Granada, y va a constituir un rasgo distintivo del retablo tunjano y santafereño entre estos momentos y principios del XVIII.

${ }^{29}$ Archivo General de la Nación (A.G.N.-Bogotá), Fondo Residencias de Boyacá, SC.54, 23, año 1596, f. 681r. Causa criminal seguida por el fiscal y juez de residencia de Tunja contra don Pedro Pacheco Carvajal.

${ }_{30}$ Véase apéndice documental $n^{\circ} 4$.

${ }^{31}$ Al dorso de la traza consta: "Modelo del Retablo questa obligado a hazer andres granado para la cofradía y ermandad de Nra. Señora de la Soledad de que tiene otorgada escriptura ante mi en veite. Y nueve días del mes de mayo de mil y quios. Y ochenta y seis as. Firma: Joan de Vargas (rúbrica)". Archivo Histórico Regional de Boyacá, Notaría 1 ${ }^{\mathrm{a}}$ de Tunja, leg. $n^{\circ} 44$ (1586), fol. 59 v. 
El apartado iconográfico también está indicado en la traza, aunque de forma incompleta. La titular de la cofradía, Nuestra Señora de la Soledad, ocuparía la hornacina inferior izquierda, en el centro un Crucificado y la imagen de la Magdalena y a la derecha la escultura de San Juan, suponemos que Evangelista. En el segundo cuerpo faltan las leyendas alusivas a la iconografía de las dos pinturas de los registros laterales, señalando Granado únicamente "pintura". El contenido del nicho intermedio era un Resucitado, advocación que tuvo gran difusión durante el XVI en territorio americano y en el caso de la Nueva Granada queda testimoniado en los envíos escultóricos de Bautista Vázquez el viejo, uno de los cuales fue la Resurrección, localizado por Margarita Estella en la iglesia bogotana de Monserrate ${ }^{32}$.

Este modelo de retablo debió marcar tendencia a partir de aquellos años, a no ser que fueran otros retablos anteriores los que impusieron tales constantes y el del humilladero no haría más que seguir lo previamente ensayado. La desaparición de la mayoría de las obras de esos momentos no permite establecer paralelos o atribuciones certeras. No obstante, es posible que entre las realizaciones confeccionadas a finales del XVI o primeros años del XVII, existan algunas vinculables al taller de Granado, como pudiera ser el retablo del muro del evangelio de la iglesia de Santa Clara, en el que se entroniza una Virgen moderna, acompañada de dos pequeñas esculturas de San Bernardo y un santo obispo, ambas de la época del retablo ${ }^{33}$ (Figura 4). Lo que ahora podemos percibir con mayor claridad es que el tipo de retablo tunjano del XVII, caracterizado por su concepción cuadriculada, rígida compartimentación de cajas delimitadas por columnas que crecen en número a medida que avanza el siglo, con veneras, motivos de abanico en los remates y creciente acento ornamental a base de recursos florales, tiene su origen hacia la década de los ochenta del XVI, constituyendo la traza que estudiamos un buen referente para comprender mejor la génesis de la retablística tunjana y neogranadina.

Llegados a este punto, merece indagar en la localización de la capilla o ermita del humilladero, donde radicaba la cofradía o hermandad de la Soledad, al parecer integrada por gente principal, descendientes de conquistadores, o españoles que alcanzaron fortuna en la ciudad boyacense. Desconocemos la fecha de su desaparición, que suponemos debió acontecer en el siglo XIX o principios del XX. Los escasos datos que nos brinda la bibliografía nos permiten intuir la ubicación de la misma en una de las calles reales, actual 19, a la altura de la tercera cuadra desde la

32 ESTELLA MARCOS, Margarita: "Dos esculturas probables de Vázquez el viejo: un Resucitado en Bogotá y el San Jerónimo de Llerena”, Archivo Español de Arte, 237, pp. 58-63; y GILA MEDINA, L. y HERRERA GARCÍA, F. J.: "Escultores y esculturas...", op. cit. pp. 516-517.

${ }^{33}$ HERRERA GARCÍA, F. J. y GILA MEDINA, L.: "El retablo escultórico...”, op. cit., pp. 343-346. 
plaza mayor. En ese lugar se hallaba uno de los principales accesos a la ciudad, desde occidente, a los pies del alto de San Lázaro, donde se iniciaba el camino hacia Samacá y Vélez. En el plano de Tunja elaborado en 1623 con motivo de la división parroquial, se puede apreciar en medio de la citada calle, una cruz a modo de crucero, quizás elemento próximo al humilladero. No debió ser edificio de gran entidad pues no figura referenciado en la descripción que de la ciudad se efectuó en $1610^{34}$. Con frecuencia la documentación lo cita inmediato al hospital de San Juan de Dios que se localizaba en la tercera cuadra de la indicada calle real de dirección este-oeste. Inmediato o integrado en el mismo se dispondría esa pequeña capilla donde recibía culto la Soledad ${ }^{35}$. También por la calle real entraba la acequia que llevaba el agua a la plaza mayor. Consta desde el XVI, que una de las cajas del agua se encontraba en el solar que ocupaba el hospital de San Juan de Dios ${ }^{36}$. Una escueta mención de las actas capitulares informa, a comienzos del XVIII, que desde la caja mencionada la acequia salía a la calle real, entre la casa de Pedro Niño y el humilladero ${ }^{37}$. Conocemos por Vicenta Cortés la situación de la morada de Pedro Niño, en la misma manzana del hospital, en la esquina con la carrera $12^{38}$. Magdalena Corradine coincide en la localización del hospital e inmediato, quizás incorporado al mismo, estaría el humilladero de la Soledad, limítrofe con la casa de Pedro Niño ${ }^{39}$ (Figura 5).

\section{APÉNDICE DOCUMENTAL}

\section{Documento 1}

1606. Santafé. Constituciones sinodales promulgadas por el arzobispo Bartolomé Lobo Guerrero.

Archivo General de Indias (A.G.I.), Gobierno, Audiencia de Santafé, 969, N. 119.

"Los ornamtos. para el servicio de las Yglesias de los Yndios.

${ }^{34}$ CORTÉS ALONSO, V.: "Tunja y sus vecinos", op. cit. pp. 155-207; y MORALES FOLGUERA, J. M.: Tunja. Atenas del Renacimiento..., op. cit. pp. 73-79.

${ }_{35}$ PORRAS COLLANTES, E.: Crónica colonial de Tunja..., op. cit. pp. 143 y 145.

${ }^{36}$ El hospital, fundado en 1553 con el título de la Concepción, siendo su rector el mayordomo de la cofradía homónima, pasó en 1636 a los hermanos de la orden hospitalaria de San Juan de Dios. Ibidem, pp. 173-174. Desde 1777 se le denominó de San Juan de Dios, ubicándose en el antiguo claustro jesuita. En 1822 pasó al convento de San Agustín y en 1864 al convento de Santa Clara, recibiendo entonces el nombre de hospital de la Caridad. http://www.hospitalsanrafaeltunja.gov.co (Consultado el 5-10-2016).

${ }^{37}$ PORRAS COLLANTES, E.: Crónica colonial de Tunja ..., op. cit. p. 266.

${ }^{38}$ CORTÉS ALONSO, V.: "Tunja y sus vecinos", op. cit., p. 171.

39 CORRADINE MORA, Magdalena: Vecinos y moradores de Tunja 1620-1623. Tunja, 2009, pp. 287 y 353. 
Altar de piedra adoves o ladrillos $=$ hierros para hacer ostias $=$ un retablo o ymagen $=$ dos manteles $=$ dos corporales con sus hijuelas y patenas $=$ dos frontales de seda $=$ dos cornualtares $=$ una alphombra o manta para la peana del altar $=$ vinageras de plata $=$ dos palias $=$ dos paños de manos $=$ un calix de plata con su patena y funda $=$ dos paños de calixes $=$ una bolsa de corporales $=$ una campana para el altar $=$ otra campana grande para el campanario $=$ un tabernaculo de madera $=$ un relicario de plata $=$ una lampara para el Ssmo. Sacramento donde uviere Yglesia de teja $=$ dos casullas $=$ dos amitos $=$ dos albas $=$ dos zingulos $=$ un yncensario $=$ cruz pequeña para el altar = una cruz con su ymagen para las procesiones $=$ una caldera pequeña o bacineta para el aspergesme = una andas y un paño negro para los muertos = un cajon de madera para los ornamtos. Una linterna para llevar la extrema uncion $=$ una cadena de alquimia o tafetan para los matrimonios $=$ un missal o dos $=$ un atril $=$ para el Baptismo una pila de piedra oradada $=$ chrismeras de plata $=$ capillos para los q. Se baptizan $=$ Manual para esto y los demas sacramentos = Un libro blanco a donde se asienten los baptizados y muertos = todo lo qual soliciten los curas con los encomenderos o oficiales de S. M. recurriendo (si fuere necesario) al Sor. Arzobpo. O Sor. Presidte. Para q. Se egecute."

\section{Documento 2}

1599-XI-27. Santafé. Alonso Diez Garfias, notario apostólico, da cuenta de las penas impuestas por el visitador general, en la visita ordenada por el arzobispo Bartolomé Lobo Guerrero.

A.G.I., Gobierno, Audiencia de Santafé, 226, N. 68 e.

"Condena a Diego Ortiz por tener la Yglesia de caña sin embarrar por de fuera y faltarle un rretablo en pena de seis pso. Que aplico la tercia parte para el rretablo de la Yglesia mayor de Velez y las dos tercias partes para gastos de visita.

A Josephe de desa condeno por faltar en el pueblo de sto. Cotes [¿Mogotes?] De su encomienda Yglesia y no tener Retablo ni campana en seis pso. Q. aplico la tercia pte. Para el rretablo de la Yglesia mayor y las dos tercias partes para gastos de visita.

Condeno a Sebastian quintero por faltarles en las Yglesias de los pueblos de Ybague y cuyamada rretablo en seis pos. Que aplico para el rretablo de la Yglesia mayor de Velez la tarcia parte y las dos tercias partes para gastos de visita.

Condeno a Jhoan de Leon por faltar en el pueblo de Roasaque un rretablo y la iglesia tenerla por enbarrar y en el pueblo de nomesaque un rretablo y una campana en seis pesos del dho. Oro corriente que aplico la tercia pte. Para el rretablo de la iglesia mayor de Velez y las dos tercias partes para gastos de visita.

Condeno a Diego Sanchez Galván por faltarle en la Yglesia del pueblo de Payma [¿Payme?] de su encomienda un retablo y la iglesia por enbarrar por ser de caña en seis pso. Del dho. Oro corriente que aplico la tercia para para el rretablo de la iglesia del dho. Pueblo de Velez y las dos tercias partes para gastos de visita. 
Condeno a Jhoan de mendosa por faltar la Yglesia de Guayaca de su encomda. Un rretablo en pena de seis pso. De oro corriente que aplico la tercia parte para la Yglesia del dho. Pueblo de Velez y las dos para gastos de visita.

Condeno a Jhoan de Leon encomendero de chinchon por no tener misal ni manual ni Yglesia ni rretablo en diez y ocho pesos de oro corriente que aplico las dos partes para gastos de visita y la una para obras pías.

Condeno al Capn. Benito Franco por fartarle en el pueblo de chimana unas puertas de madera con serradura y llave en la iglesia del dho pueblo y un rretablo en pena de quatro pso. Que aplico p. gastos de visita.

Condeno a Jhoanes de Ugarte administrador del pueblo de Batarequa [¿Butaregua?] de la encomda. De Hortega de morales por faltarle puertas de madera y serradura y llave y un rretablo en la iglesia del dho. Pueblo en pena de qtro. Pso. Para gastos de visita.

Condena a sebastian de el santo encomendero de Ubigara por fartarle en la iglesia del dho. Pueblo puertas de madera y serradura y llave y un retablo en qtro. Pso. Y en las costas de visita.

Condeno a Marcos de Murçia encomendero de Guaneta por faltarle en la iglesia del dho. Pueblo un rretablo y una campana y en la puerta una serradura con su llave en seis pso. De oro corriente y en las costas de visita.

Condeno a Jhoan de mayorga encomendero de Moncora por fartarle un rretablo y una campana y una serradura con llave en la iglesia del dho. Pueblo en quatro pso. De oro corriente y en las costas de visita.

A Sancho de Angulo encomendero de Corata le condeno por faltarle en la Yglesia del dho. Pueblo un rretablo un rretablo (sic) y en la puerta serradura y llave en qtro pso. Y quatro de visita y en las costas.

Condeno a Alonso de Bega por faltarle en la yglessia del pueblo de bocore puertas de madera con llave y serradura y un rretablo en qtro pso. Y en tres de visita y en las costas.

Condeno a Sancho de Angulo encomendero de bachoque [¿Subachoque?] por faltarle en el dho. Pueblo una iglesia y un rretablo en qtro. Pso. Y en las costas de visita.

Condeno a Jhoan de castro encomendero de agueta [¿Águeda?] por faltarle en el dho. Pueblo e Yglesia del un rretablo y unas puertas con serradura y llave y una pila batismal en seis pso. De oro corriente y en las costas de visita.

Condeno a Sancho de Angulo, encomendero de Guabata por faltarle en la Yglesia del dho. Pueblo un rretablo en qtro. Pso. De oro corriente y en las costas e visita de pila e ygla.

Condeno a Joanes de Ugarte administrador del pueblo de Cota por faltarle en la Yglesia del dicho pueblo un rretablo y una puerta con su serradura y llave en quatro pso. De oro corriente.

Condeno a Pedro calvete encomendero de Saboya por faltarle en la iglesia del dho. Pueblo una campana unas andas para enterrar los difuntos una cruz con su 
manga un frontal para el altar un calis con su patena de plata una pila de Batismo un misal y todo lo demás nesçesario para poder celebrar y decir missa en diez pso. De oro corriente los tres para el rretablo de la Yglessia del dho. Pueblo de Velez y los siete para gasto de visita.

Condeno a Gaspar de Figueredo por aber faltado en la iglesia del pueblo de muniquica [¿Moniquirá?] un rretablo y una campana y unas crismeras en seis pso. De la visita."

\section{Documento 3}

1586-V-29. Tunja. Andrés Granado, carpintero, se obliga a confeccionar un retablo para la cofradía de la Soledad, ubicada en el humilladero de la ciudad.

Archivo Histórico Regional de Boyacá. Notaría $1^{\text {a }}$ de Tunja, leg. 44, ff. 60r-62r.

"Sepan quantos esta carta vieren como yo andres granado carpintero vez desta zibdad de Tunja del nuevo rrei $^{\circ}$. de granada de las Yndias, otorgo e conozco que me obligo a la cofradía de la soledad de Nra. $\mathrm{S}^{\mathrm{a}}$ y a vos el capn. Pedro Pacheco Carvajal y $\mathrm{Al}^{\circ}$ de caravajal y estevan $\mathrm{Gs}^{\circ}$. sus mayormos. en su ne. en tal manera que yo sea obligado e me obligo de hazer un tabernáculo rretablo en el umilladero de la zibdad de la manera y forma que esta dibuxado en el medio pliego de papel fyrmado del preste. sno. que esta cozido conesta escriptura y an de ser los tabernáculos del rretablo del modelo y tamaño de las figuras que en el se an de poner que son las que están en el dho. umilladero e yo el dho. e yo el dho. Andres Granado tengo de poner el trabajo de mi persona y manos y hechura y toda la clavazón que fuere menester lo qual tengo de hazer y dar fecho y acabado dentro de seis meses complidos primeros siguientes (f. 60v.) que corran y seguentes desde oy dia de la fha. desta carta en adelante y dentro del dho. termino lo he de dar asentado y a contento y vista deofiçiales q. dello entiendan uno puesto por mi parte y el otro puesto por vos los dhos. Mayordomos por rrazon de lo qual la dha. cofradia y vos los dhos. sus mayordomos aveis de ser obligado a me dar y pagar çiento y treinta pesos de oro fundido y marcado con la marca rreal de su magd. de ley e valor de vte. quilates cada un peso pagados enesta manera, los cinqta. pesos del dho. oro dellos luego como començare a hazer la dha. obra y los ochenta pesos del dho. oro rrestantes luego que acabare y asentare el dho. rretablo tabernáculo en la forma y manera que dho. es, de mas de lo qual la dha. cofradia y vos los dhos. mayordomos haveres de ser obligados de me dar toda la madera que fuere menester para hazer lo susodho. y si no fiziere e cumpliere lo susodho. que a mi costa podais (f. 61r) concertar lo susodho. con otro oficial que lo haga e cumpla en my lugar por el $\mathrm{pr}^{\circ}$. que lo pudieredes hallar y lo que mas vos costare de la cantidad que es dha. q. yo lo pague y por ello me podais executar a mi persna. y bienes con solo el juramto. de vos los dhos. mayordomos o de qualquiera de vos en que juréis y declareys la cantidad que mas costare y de cómo no es cumplido lo susodho. sin mostrar otro recabdo por otra prueba 
ni diligençia ni averiguaçion alguna ni que de dar vos requiera, de la qual vos rrelevamos y nos los dhos. $\mathrm{P}^{\circ}$ Pacheco e $\mathrm{Al}^{\circ}$ de Carvajal y Estevan Gso. que a todo lo que dho. es presentes somos otorgamos y conoçemos de mancomun y a boz de uno y cada uno ynsolidum como mayordomos de la dha. cofradia de la soledad de nra. Sra. de dar e pagar y que daremos y pagaremos a vos el dho. Andres Granado los dhos. çiento e treynta pesos de oro de veynte quilates a los dhos. plazos (f. 61v) e según de suso se contiene y de cumplir todo lo demás que es a cargo de la dha. cofradia syn falta alguna e pa. lo asy pagar e cumplir todo como dho. es nos los dhos. Mayordomos obligamos los bienes y rentas de la dha. cofradia ávidos e por aver y yo el dho. Andres Granado obligo mi pers ${ }^{\mathrm{a}}$ e todos mis bienes abidos e por aver y damos poder cumplido nos los dhos. mayordomos a las justiçias que de encausa devan conocer e yo el dho. Andres Granado a los juezes e justiçias de su magd. ante quien esta carta fuere presda. para que por todo rigor de dro. compelan a mi el dho. Andres Granado y a los bes. de la dha. cofradia a lo asy pagar e cumplir (...) (f. 62r) Otorgada en la dha. ciudad de Tunja a veinte e nueve días del mes de mayo de mil y quios. ochenta e seis aos. y los dhos. otorgtes. q. yo el son. puc ${ }^{\circ}$ doi fee conozco lo firmaron de sus nes. siendo tgos. prestes. Marcos de podada e fernan ruiz de Ahumada e $\mathrm{Ju}^{\circ}$ Sánchez. rrestes. en esta dha. ciudad.

$\mathrm{P}^{\circ}$ Pacheco Carvajal (rúbrica).

Estevan $\mathrm{G}^{\mathrm{z}}$ (rúbrica).

Andres Granado (rúbrica).

Dros. a Lxxv por oja."

Ante mi Joan de Vargas (rúbrica)

\section{Documento 4}

1596. Tunja. Interrogatorio para averiguación de ciertos hechos acaecidos en la celebración de la Semana Santa de 1593.

A.G.N., Fondo Residencias de Boyacá, SC. 54, 23, año 1596, ff. 610v-611r.

"Y si saben que en la dicha ciudad desde que se fundó la Cofradía de la Veracruz de la Sangre siempre acostumbrado salir a la una después de media noche por ser así la concesión de la bula para que gocen y ganen de las indulgencias del Jueves y Viernes Santos y el dicho doctor Barrosos por mandamiento de la sede vacante quiso hacer novedad en ésta el año de noventa y tres y que los cofrades y procesión se diese de día y todos los cofrades unánimes contradijeron y no quisieron salir sino de noche a la hora acostumbrada y sobre ello se hicieron sus autos y requerimientos y si aquel día día hubo algunos corrillos de personas o algún alboroto fue en razón de esto y no de otra cosa y entre los mismos cofrades de la dicha cofradía los quales estuvieron en su opinión de no querer salir de día y así no salieron de día ni de noche y por no salir aquella noche la cofradía y cofrades juntos andaban de cuatro en cuatro y de seis en seis en sus estaciones sin que hubiese escándalo ni alboroto como está dicho y lo saben porque lo vieron y se hallaron a todo presentes. 
Y si saben que el dicho Pedro Pacheco como fundador y hermano de la Cofradía de la Soledad sin embargo de la resistencia que los dichos cofrades hicieron sobre salir la procesión de día, sacó las insignias de su casa y las puso en la Iglesia Mayor de la dicha ciudad y públicamente aconsejó a los cofrades diciéndoles que pues el Ordinario los mandaba salir la dicha procesión de día se tenía bien mirado y que la mejor disciplina que podían hacer era la obediencia y que saliesen cuando les fuese mandado.

Y si saben que en todo el Pirú en Nuevo Reino de Granada ha sido y es costumbre usada y guardada de los días del Jueves Santo velarse las ciudades con gente de a caballo y de a pie, entre tanto que el Santísimo Sacramento está encerrado de día y de noche guardando esta costumbre se hizo lo propio en la dicha ciudad de Tunja el Jueves Santo del año de noventa y tres y no digo otra cosa particular alguna porque no se hiciese el dicho día y noche en la ciudad y así no causó novedad ni alboroto en la dicha ciudad y vecinos de ella."

Fecha de recepción: 6 de octubre de 2016

Fecha de aceptación: 4 de enero de 2017

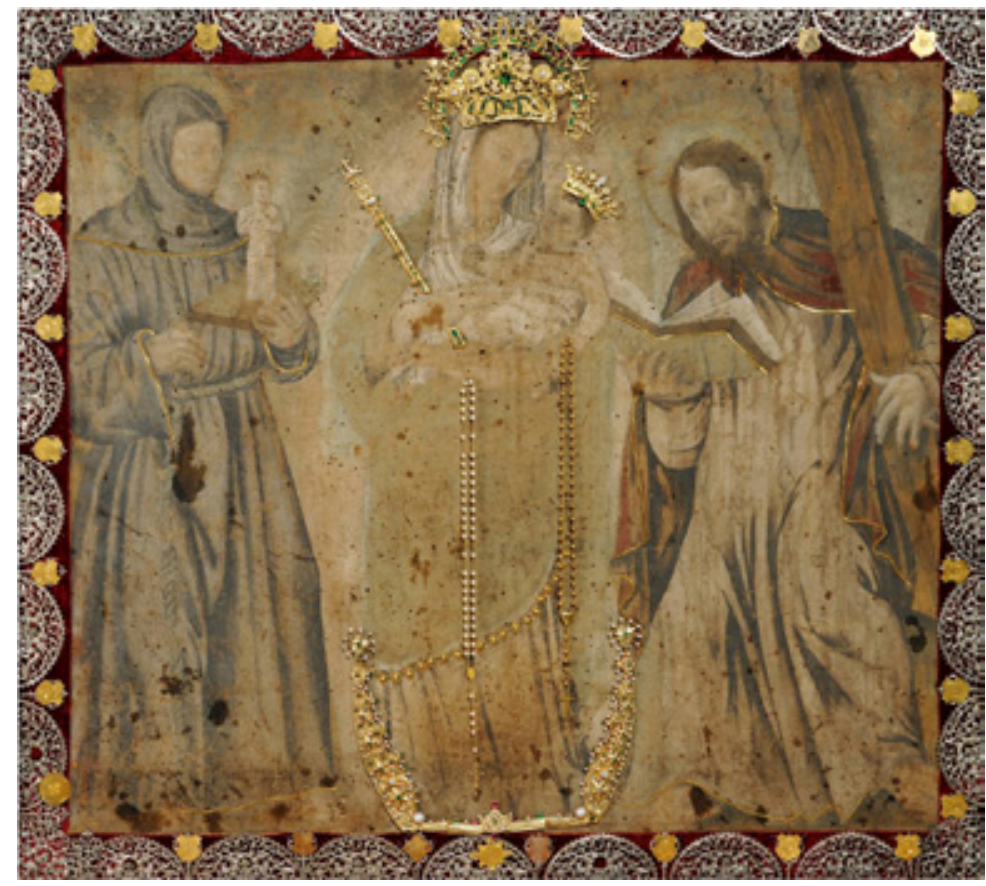

Figura 1. Alonso de Narváez, Nuestra Señora del Rosario de Chiquinquirá, hacia 1555-1562, temple sobre manta de algodón, 119 x $125 \mathrm{~cm}$, basílica de Chiquinquirá (Colombia). 


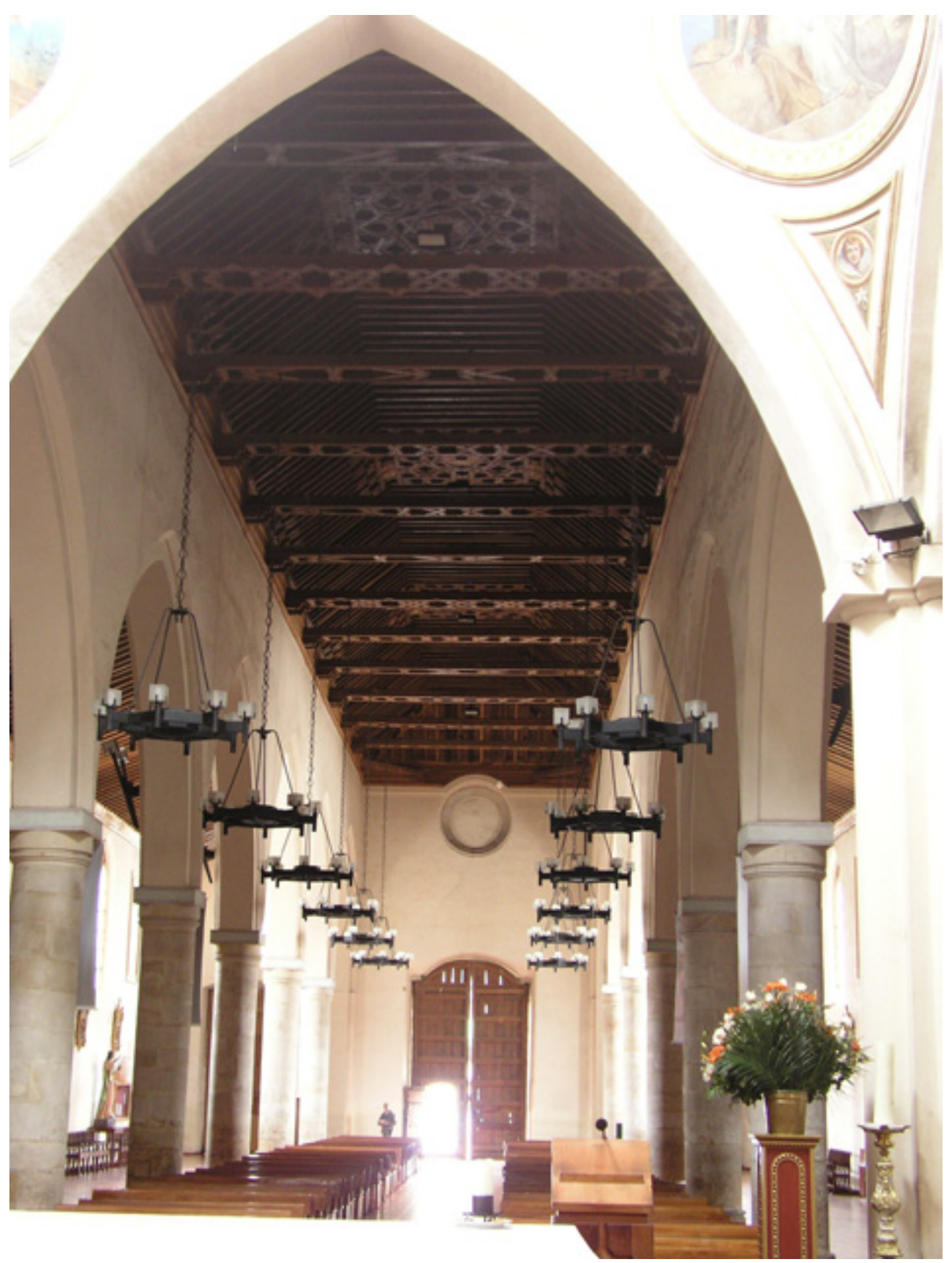

Figura 2. Bartolomé Moya, Artesonado de la iglesia mayor, actual catedral (detalle), 1572-1574, Tunja (Colombia). 


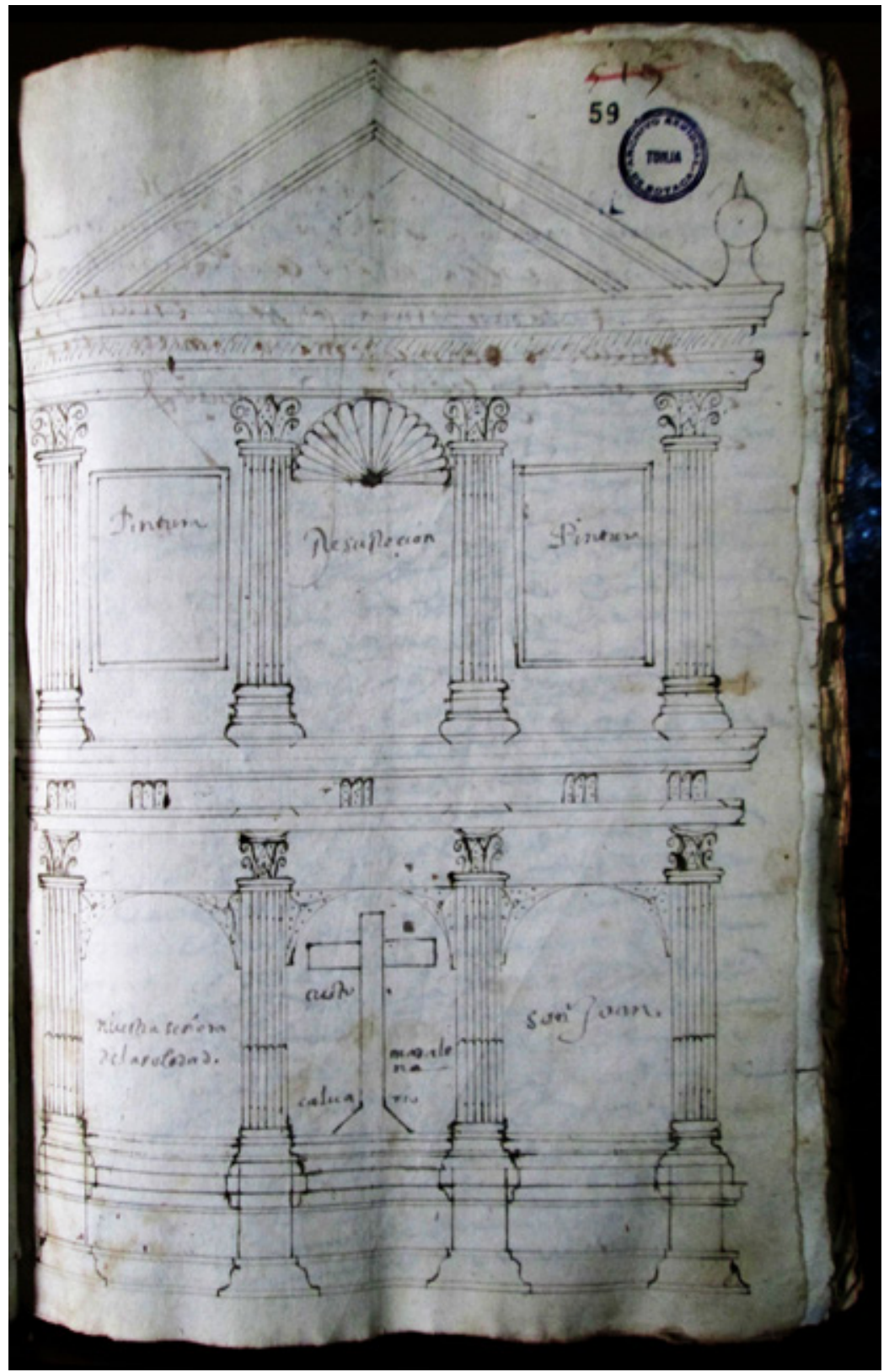

Figura 3. Andrés Granado, Trazas para el retablo de la Hermandad de la Soledad del humilladero de Tunja, 1586. A.H.R.B., Notaría $1^{\mathrm{a}}$ de Tunja, leg. $n^{\circ} 44$ (1586), f. 59r. 


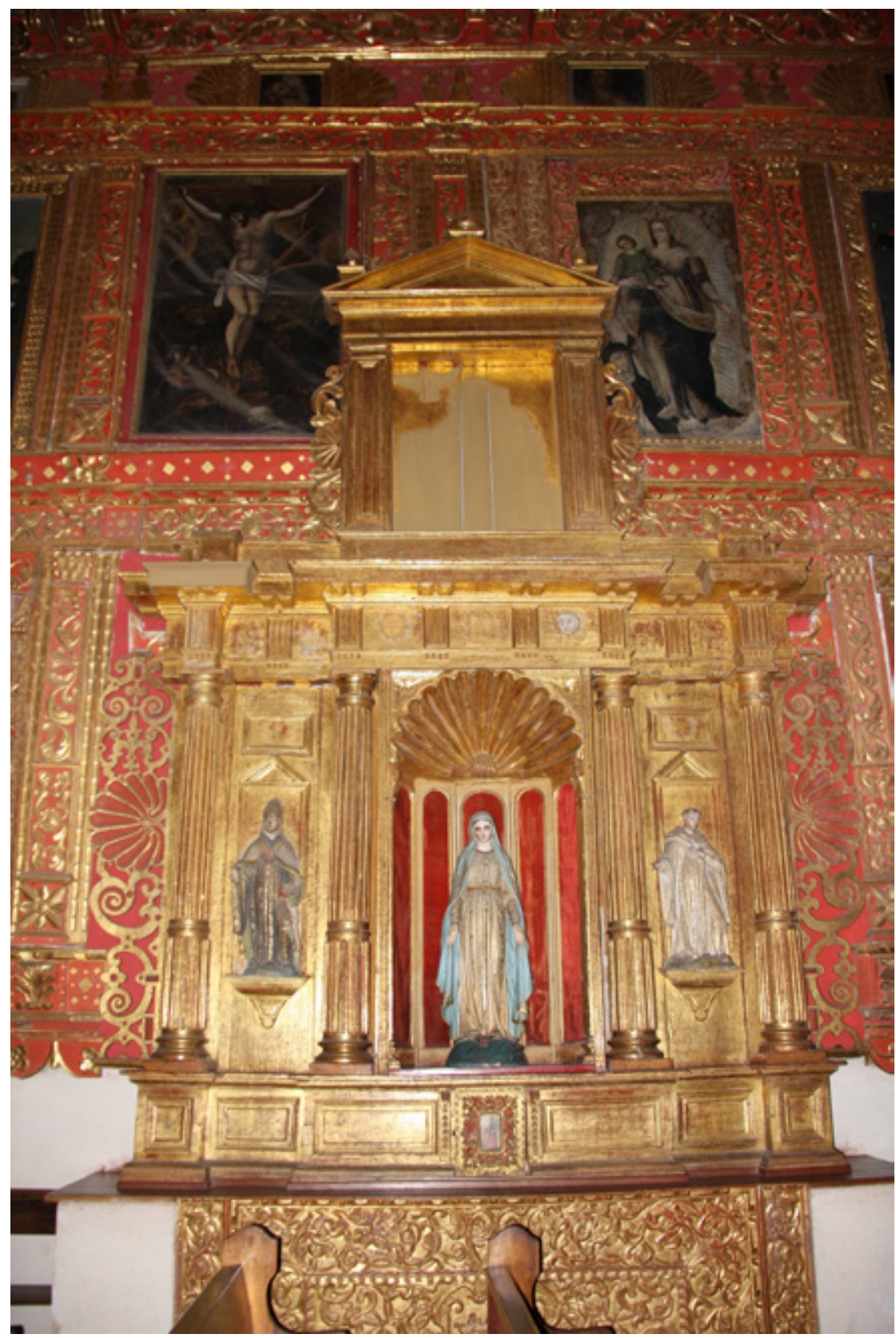

Figura 4. ¿Taller de Andrés de Granado?, Retablo lateral, hacia 1590-1610, Iglesia de Santa Clara, Tunja (Colombia).

LABORATORIO DE ARTE 29 (2017), pp. 207-228, ISSN 1130-5762 e-ISSN 2253-8305 - DOI http://dx.doi.org/10.12795/LA.2017.i29.10 


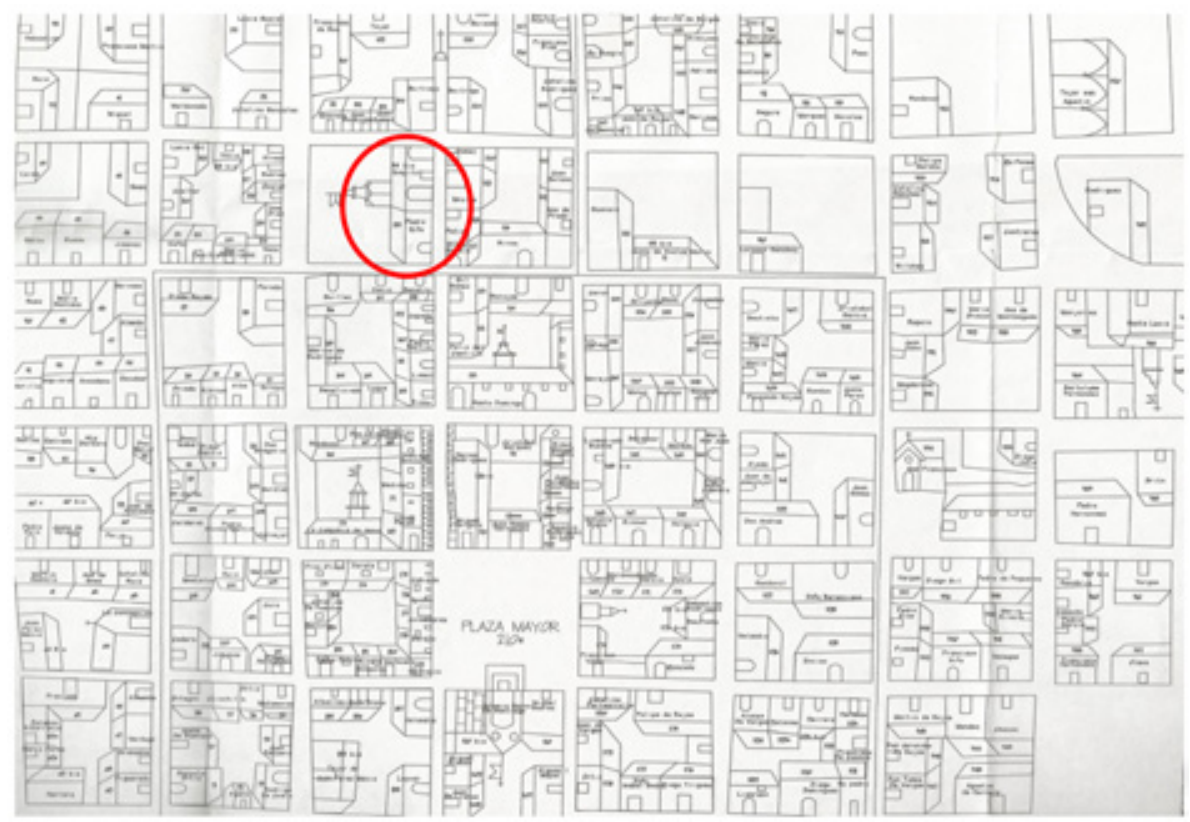

Figura 5. Plano de Tunja (fragmento) elaborado a partir de la planta de 1623, en el que se señala la situación del hospital, casa de Pedro Niño y humilladero. Elaborado por la arquitecta Mery González Terán (CORRADINE MORA, Magdalena: Vecinos y moradores de Tunja, 1620-1623. Tunja, 2009, pp. 317-318). 